\title{
Recent methods, sources and approaches in the study of temporal landscape change at different scales - a review
}

\author{
ANDERs LUNDBERG ${ }^{1}$
}

\begin{abstract}
Landscape change can be studied at different scales, from local to regional, e.g. from a biodiversity level to the level of land-use systems. Historical sources such as land taxation papers, cadastral maps, agricultural and population censuses are not very much used in physical geography studies but this article explores the potential of historical sources and gives examples of how they can be used. Studies of landscape change requires an approach to the temporal dimension and examples are given on how this can be solved. At the biodiversity level, much attention is presently paid to red-listed species. The article gives an account of criteria used to evaluate red-list status of species and critically reviews the way governmental nature management bodies presently deal with this. Several long-term studies have been carried out recently and huge variations in population size of species from year to year have been detected. As an alternative to red-list status based on population size based on static data from one or a few years, the concept of the natural variation interval of a species is introduced. The article demonstrates how this phenomenon can be identified based on a temporal approach.
\end{abstract}

Keywords: temporal landscape change, time-series, red-list criteria, natural variation interval, historical forest cover measurements

\section{Introduction}

Landscape change is more than ever a characteristic feature going on across the world (Heatherington, C. et al. 2017; Belén, M. et al. 2018). Changes in settlement patterns, land-use and climate change are well known reasons for changes in vegetation and biodiversity (DєÁк, B. et al. 2016, 2018; Kızos, T. et al. 2018; Тӧвӧк, P. et al. 2018). Loss of biodiversity has become a major concern all over the world and criteria to evaluate biodiversity loss developed by the International Union for the Conservation of Nature (IUCN) have been adopted by numerous countries. In Norway, 4,438 species are redlisted according to the recent up-date of 2015 (Henriksen, S. and Hilmo, O. 2015). Habitats and ecosystems also undergo change, and several nature types have become threatened. At present, 75 nature types are considered threatened in Norway, and 39 nature types are considered near threatened (LINDGAARD, A. and Henriksen, S. 2018). In total, nature is under press, both species and ecosystems, even in a country like Norway, often valued for it's beautiful natural landscapes. The aim of the study is to elaborate how temporal landscape change can be studied at different scales: at landscape, population and species levels, emphasizing the temporal dimension.

\section{Approaches to the study of landscape transformation through time}

Changing landscapes is one major characteristic of recent environmental change across Europe. Urban sprawl is a dominant process, as well as changes in the settlement patterns due to urbanisation (Couch, C. et al. 2007). Agriculture is changing from small-scale to large-

\footnotetext{
${ }^{1}$ Department of Geography, University of Bergen, Fosswinckelsgt. 6. 5007 Bergen, Norway.

E-mail: anders.lundberg@uib.no
} 
scale, from diversity of crops and livestock to specialisation and production with lots of input of external resources. Natural landscapes are transformed to recreational landscapes, some with new and modern technical installations, such as cable cars to mountain tops. Seascapes are also changing from natural fiords and coasts to fish farming production systems. To study these and similar questions belong to the core of academic geography, and such studies have links to both physical and human geography (JonEs, M. 1988; LundBERG, A. 2005a, b; SKJEGGEDAL, T. 2005).

Methods used to study landscape change include aerial photo interpretation, remote sensing, GIS, vegetation mapping and others. Comparison of aerial images of different age has proved highly useful to detect temporal changes in land-use, settlement patterns, roads and other types of infrastructure, forest increase/decrease, development of river meandering etc. (Plieninger, T. 2006; Hill, J. et al. 2008; Frondoni, R. et al. 2011; Novák, T.J. et al. 2014; Szabó, S. et al. 2015). Another supplementary source that can be used to analyse temporal landscape change is the use of historical sources, such as cadastral maps, historical land taxation papers, population and agricultural censuses. These historical sources are well known among historians but less so among geographers and ecologists. Some ecologists implement historical data in their studies of habitats and species diversity though (Helm, A. et al. 2006; Pitkänen, P.T. et al. 2016). They include information about land-use at certain times, extent of forests, meadows, pastures, cultivated fields, livestock and other types of spatial data that can be transformed and used in the analysis of changes in landscape (TöвöK, P. et al. 2010). In other words, these historical data can be used in the reconstruction of past landscapes (Y $\mathrm{YANG}_{\mathrm{A}} \mathrm{Y}$. et al. 2017). Historical data can be used to study when physical landscape attributes appeared, how they developed, changed and disappeared and sometimes also reappeared. The static map can then be transformed to a complex and ever-changing mosaic of spatial phenomena that rise, meet, connect, separate and disappear (Hägerstrand, T. 1995; Lundberg, A. 2008).
LUNDBERG, A. (2005b) used historical sources to study forest development in Western Norway during the last 400 years. Forests invaded Western Norway in the late Holocene period (c. 12,000 B. P.) and different trees succeeded as climate became milder after the last Ice Age. The first tree to colonise Northern Europe after the last Ice Age was the birch, and thermophilous decedious trees were late invaders, such as elm, oak, lyme, and ash. The cultivation of land started in the Younger Stone Age period and production of cereals became common in the Bronze Age. In Medieval times the settlement pattern was consolidated but forests were still extensive and covered most parts of the land below the alpine tree limit. Forests were harvested and timber was used for building houses, boats and a number of things but open land was mostly minor patches in a dominant matrix of forest.

This situation changed rapidly due to the introduction of water-driven saws in the $14^{\text {th }}$ century. Previously, the axe was the dominant tool in forestry but this was time-consuming. Water-driven saws were more efficient and effectively split logs into building planks. During the $14^{\text {th }}$ and $15^{\text {th }}$ century forestry became a major industry in Western Norway and timber and planks were even exported to Holland and Scotland. This trade is called the Scot forest trade.

At the same time cities developed along the coast, such as Bergen and Stavanger. Most houses were built of timber, a resource available in regional forests. However, sometimes Bergen and other cities were hit by devastative fires and major parts of the cities burnt and had to be rebuilt. Timber was still available regionally but Bergen and other cities burnt again and again (BÆKKEN, I. et al. 2002). As a result of Bergen fires and the Scot forest trade Western Norway was deforested during the $15^{\text {th }}$ century. Population increase and extensive livestock grazing along the coast, in fiord valleys and mountain pastures prevented the reestablisment of forest.

Land-use was intensified to a maximum and this lasted until the end of the $17^{\text {th }}$ century when the emigration to America had it's peak. 
Only then forests started to re-develop, and this is why many forests in Western Norway can be dated back to the 1880s or so. Forests older than this can be found but they are scattered.

LundBerg, A. (2005a) used historical sources found in statal archives to reconstruct forest development in a part of Western Norway. Sources used were land taxation papers from 1665, 1723, 1867 and 1890, cadastral maps from 1825 and 1881, as well as areal photos (from 1956 and later), interviews and finally field registrations. The result is presented in Figure 1.

The result varies quite a bit from the general conclusions drawn by botanists prior to this research. Due to the luxourious vegetation the forest was interpreted as a primeval forest but thanks to the analysis of historical sources it turned out that the forest was a young, first generation forest (LuNDBERG, A. 2005a,b, 2010) . As can be imagined, this will very much impact the management of such a forest. This is because an old primeval forest would be in a mature state of development, while in a young, first generation forest more dynamics would be expected.

Core concepts in academic geography is the combination of time and space/place (Holt-Jensen, A. 2018). Historical geography has very much been involved in the study of landscape change and how different landscape attributes arise and develop. Any landscape is many-facetted and always include human and natural phenomena and combinations of those. Specialisation with focus on certain phenomena has been a de-

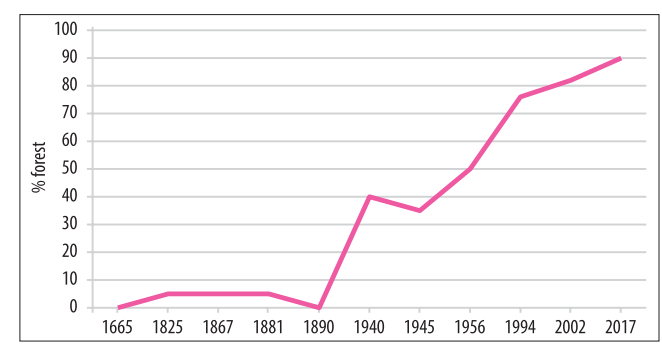

Fig. 1. Forested areas in percent of land area in a part of Western Norway during 1665 to present. Source: Based on LundberG, A. (2005a), but revised and updated.

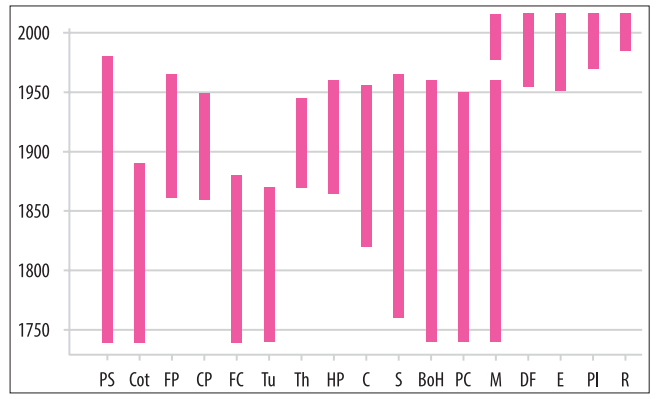

Fig. 2. Time-scale illustrating major factors, activities and land-use that characterised a landscape during certain periods of time. The approach is diverse more than limited (revised from LundBERG, A. 2002). - PS = permanent settlement; $\mathrm{Cot}=$ cottagers; $\mathrm{FP}=$ farm production; $\mathrm{CP}=$ cereal production; $\mathrm{FC}=$ fields cultivated with spades; $\mathrm{Tu}=$ tust; $\mathrm{Th}=$ threshing; $\mathrm{HP}=$ horse and plough; $\mathrm{C}=$ cattle; $\mathrm{S}=$ sheep; $\mathrm{BoH}=$ burning of heathlands; $\mathrm{PC}=$ peat cutting; $\mathrm{M}=$ mowing; $\mathrm{DF}=$ deciduous forest; $\mathrm{E}=$ electricity; $\mathrm{Pl}=$ plantations; $\mathrm{R}=$ recreation

veloping trend in recent landscape research. An attemt to reach beyond specialisation and achieve a wide scope on landscape and landscape change is presented in Figure 2.

Data supporting Figure 2 has been collected using population and agricultural censuses, interviews of local informants, and aerial photo interpretation. A number of factors, activities and land-use that have influenced the landscape is presented along the x-axis, such as permanent settlement, cattle keeping, burning of heathlands, peat cutting, expansion of forests etc. The year different facors were initiated, continued and eventually came to an end is shown along the y-axis. This way of illustrating landscape development adopts a wide scope dealing with major elements that characterise a landscape during a given period of time.

\section{Methods to monitor biodiversity dynamics}

Criteria used in many national red-lists include population reduction, geographical range, small population and continuing decline in population, and very small or geographically very restricted population (HENRIKSEN, S. and Hilmo, O. 2015). 
One essential criteria for evaluation of the red-list categories is the trend during the last ten years. For many species we have information about distributions but one challenge is lack of data on temporal change in numbers and density. Consequently, red-listing has to be based on best knowledge and judgements, more than systematic empirical data on temporal population trends. Some taxonomic groups are known to have extensive changes in abundance from year to year, e.g. orchids. This might also be true for other taxonomic groups but empirical evidence on this is limited. This is a major challenge for red-listing of species. If information is based on the situation in an unfavourable year, a species might be given status as threatened; if information is based on the situation in a good year, the status might be considered near threatened. The actual status for that species may not have changed, but the evaluation of the situation might be very different depending on the situation in one or a few incidental year(s).

An example is the status given to the orchid Coeloglossum viride ssp. islandica in the Norwegian red-list of 2006. It was concluded that the taxon most likely was extinct in Norway. As demonstrated by the long-term study by LunDBERG, A. (2015) this was luckily not the case. This was not because seeds had been dormant for a period. It was simply because the taxon was less known among botanists and also because the awerness of that subspecies among botanists was low.

All nature conservation areas have some purpose and they are often explicitly mentioned in management plans of protected areas, such as nature reserves, landscape protection areas and national parks. In modern nature conservation, the formulation of population measures for taxonomic groups present in the protected area has also become usual. This has been done for bird species and other groups but again one challenge is that lack of data on changes in the temporal abundance of the relevant groups.

\section{The distinction between extinction and dormancy}

To investigate the range of annual variations among orchid populations a study of Dactylorhiza purpurella was started in Norway in 2012 (Lundberg, A. and Frøland, T. 2016). All known Norwegian populations were visited and a monitoring program was started. In total, 48 populations are known and 30 of these are intact, 15 have been lost and three populations have unknown status. The species is considered to be critically threatened (CR) in Norway. Some of the populations are small and some are numerous with several hundreds to a few thousand plants in a year. In Norway, D. purpurella is found in sand dune meadows and dune slacks, in salt marshes, wetlands and other wet or moist habitats close to the sea. A few populations are also found in abandonded industrial sites, probably due to the open site with mineralic, calcareous soils. D. purpurella is a North Sea species known from the UK, Denmark, Norway and the Faroe Islands (Figure 3). The Norwegian distribution is on the western coast, in the south-west and the north-west part of Western Norway. Soils are often calcareous and the sites are usually rich in species.

During the monitoring period 2012 till present all populations showed considerable variation in numbers from year to year. Huge annual variations in abundance is the normal pattern, stability in the number of plants in any population has never been found (LundberG, A. and Frøland, T. 2018) The distinct variation can not be explained by technical encroachments, because no physical change to the soil or habitat has been found. There is no one-way trend in decrease or increase so the fluctuations can not be due to climate change. The explanation we found is that lots of precipitation during late autum and the first part of spring is favorable for germination, particularily because the plants heavily depend on mycorrhiza infection in this part of the year. Intact leaves not damaged by drought the season before might also be necessary for production and storage of 


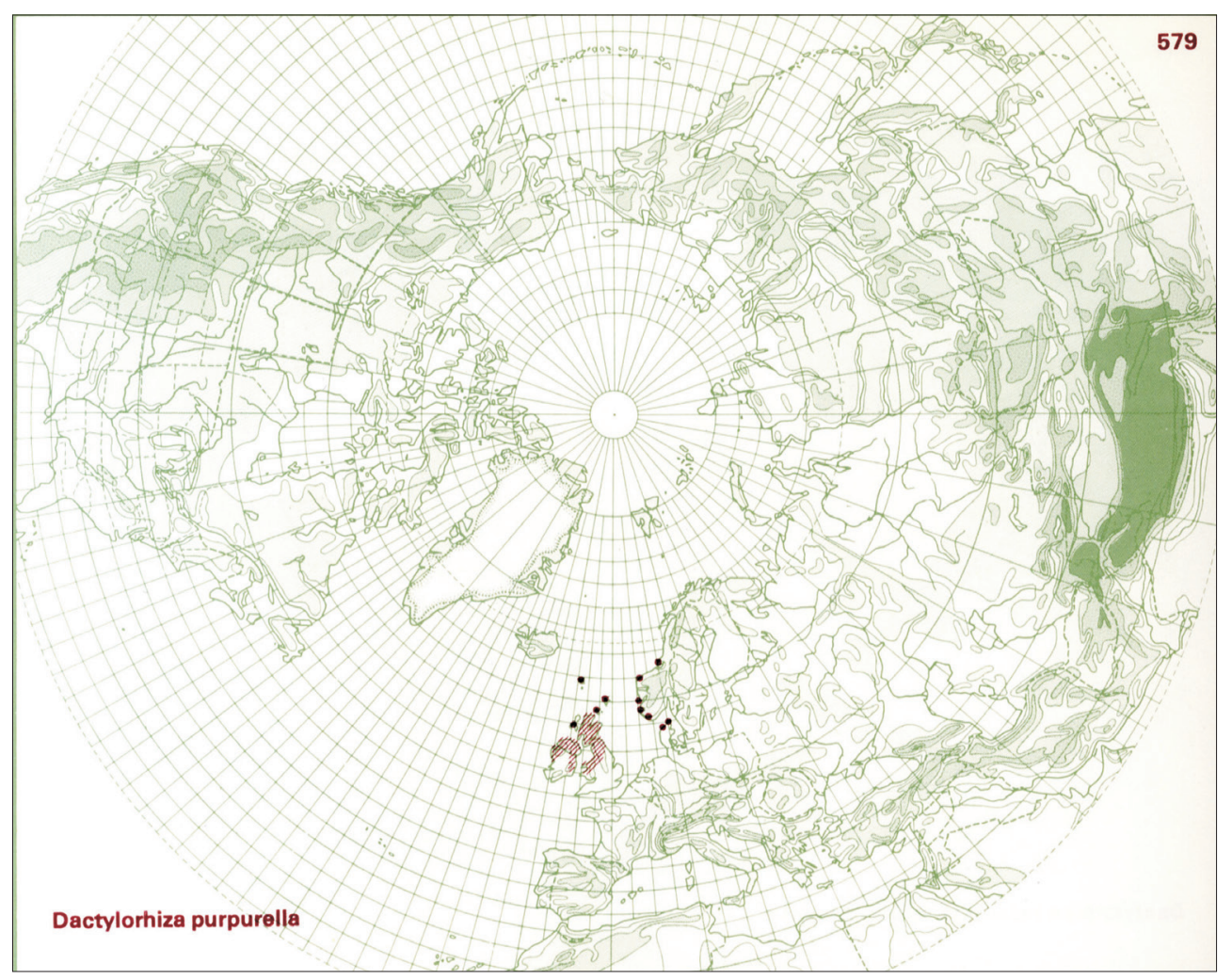

Fig. 3. The known distribution of Dactylorhiza purpurella (Hultén, E. and Fries, M. 1986).

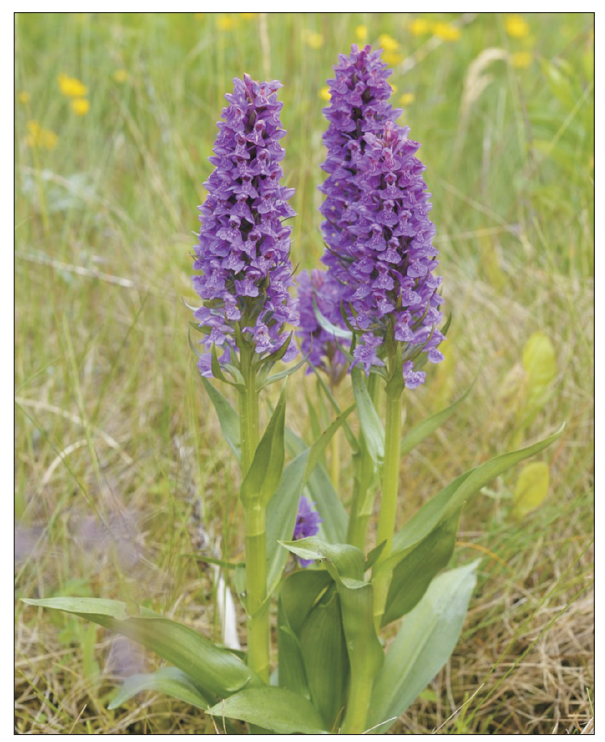

photosyntetic products to allow supply of nutrients in the following spring. If this is not the case, plants may enter hibernation. As other orchids, D. purpurella is a perennial species, and hibernation is not to be confused with decline or extinction (Photo 1).

An example of the huge range in annual fluctuations in one D. purpurella population is shown in Figure 4. Plants in this population grows in dune meadows and dune slacks. All plants were counted in six years, at the same time of the year each time. During the first four years number of plants varied from 88, 104, 63, and 98. In 2017 the number was 2,846 . If red-list status had been given in

Photo 1. Dactylorhiza purpurella (Photo by LundberG, A.) 


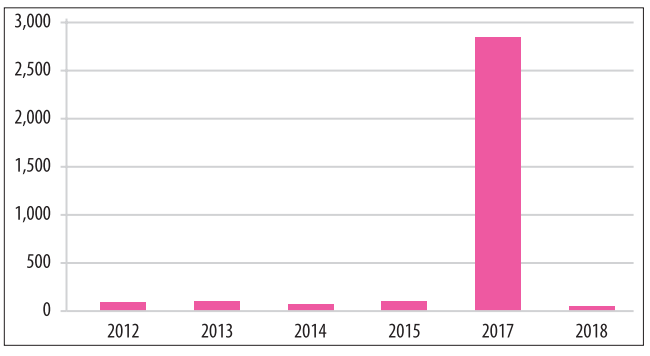

Fig. 4. Fluctuations in the number of plants of D. purpurella at Ognasanden, southwestern Norway. The first four years represent a normal situation, 2017 was a particularly favourable year for that species at that site.

2014, the judgement would have been heavily impacted by the low number of plants (63). The high number of plants registered in 2017 should not be considered as an increase but rather a peak within the natural fluctuation of that population.

Another example of the fluctuations in the number of $D$. purpurella plants that can be found in one population over time is from the site Kalveneset in Western Norway. This population has been monitored during four years, and the number of plants in those years were 546, 178, 1,274, and 682 (Figure 5). The site is untouched by technical influence and the variation from year to year has to be considered as natural fluctuation. The lesson learnt is that a time-series including several years is necessary to be able to identify the size of a popula-

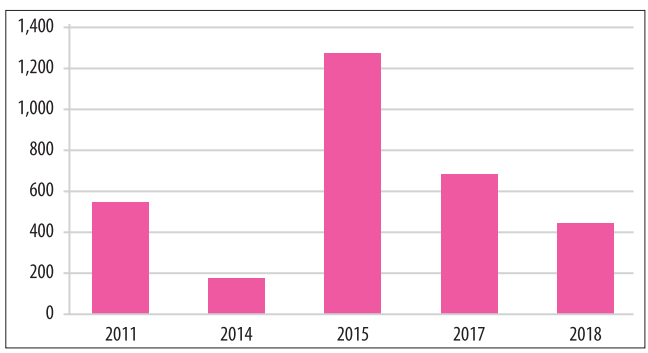

Fig. 5. Fluctuations in the number of plants of D. purpurella at Kalveneset, a population with no technical encroachments tion. The same will apply for measurements of the total number of national populations.

\section{The challenge of huge variations among annual plants}

As mentioned, it has been known that the population of orchids may vary a lot from year to year, as also demonstrated in the examples given here. However, is this a phenomenon first and foremost characteristic of orchids or will this also be the case for other plant groups? The long-term study of Aphanes australis in Norway can shed light on this question. The study was initiated in 2009 as part of a monitoring program for several red-listed species in Norway (LundberG, A. 2016). Aphanes australis is a small annual plant found on thin soil in open meadows. It is essential a European species. Its main distribution is found in continental Europe with the northernmost distribution in the Shetland Islands and in southwestern Norway (Figure 6).

All known Norwegian populations have been monitored since 2009. As mentioned, Norwegian populations of Aphanes australis are found on shallow ground, often on the fringe of pastures (Photo 2). Pastures are often heavily manured and this is a threat to $A$. australis. Several populations have become extinct because of this. On the other hand, some of the populations are not at all manured or just manured in limited quantities. Shallow soils are exposed to drought and this might be a problem for many other plant species. This is why A. australis can be found as a dominant species in appropriate environments. Populations might have a range of $1 / 2$ $x 1 / 2$ to $1 \times 10 \mathrm{~m}$. In a good year the site may be close to totally covered by $A$. australis. However, in other years the species might not be present with adult plants at all.

This might easily be confused with extinction but long-term monitoring proved that a population may enter dormancy in certain years. In Norway, the species behaves as a summer annual plant but in certain years it may also behave as a winter annual. 


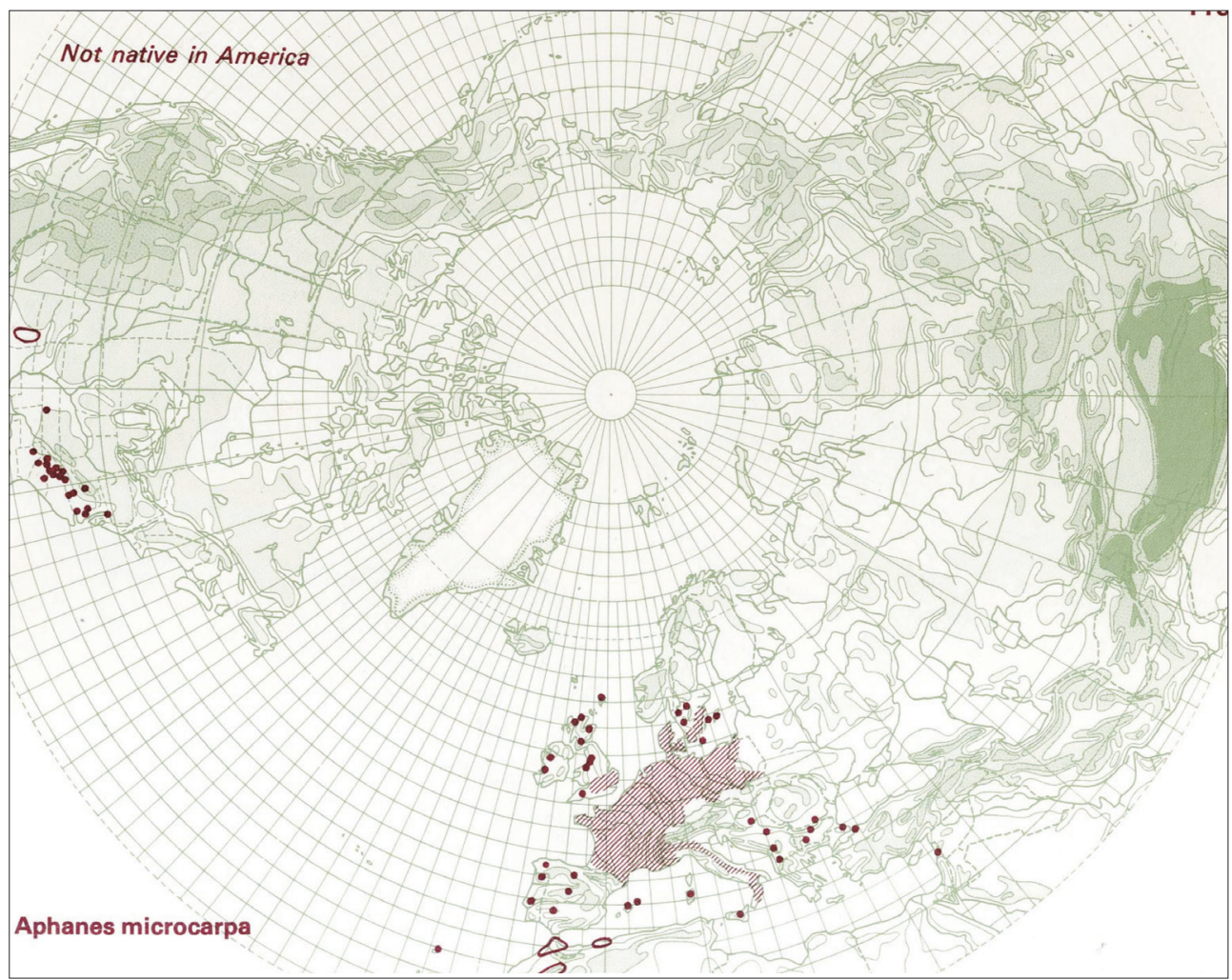

Fig. 6. The known distribution of Aphanes australis, primarily a European species (HultéN, E. and FrIEs, M. 1986). Norwegian populations were not known in 1986 and are not included in the map.

Temperature is the major factor having an impact on germination, but also darkness, light and water. The rate of germination at different temperatures, humidities and light conditions proved to be governed by a continuum between dormancy and germination (BASKIN, C.C. and BAskin, J.M. 2014; Lundberg, A. 2016). The total number of plants in Norway varies between $<250$ in a bad year and $<20,000$ in favourable years (LundBerG, A. 2016; Figure 7). It is easy to imagine that this can make a huge difference for the judgement of red-list status for such a species. The size of a population and the total number of populations in a country in one year cannot be used to decide red-list status. Long-term monitoring is essential to be able to identify the normal and natural fluctuation interval of a species. The problem is that such time-series are hard to find for most vascular plants and also other taxonomic groups. To obtain long-term time-series for most species is beyond any possibility but to develop some time-series of this kind should be a major target for governmental environmental bodies in all countries.

The recent Norwegian red-list for species takes into account precise terms and definitions as suggested by the IUCN, but when they are operationalised they cannot be supported by precise data, simply because such data hardly exist. Terms applied are "continuing decline in the extent of occurrence", "continuing decline in habitat quality", "continuing decline in the number of localities or subpopulations", "continuing decline in the number of mature individuals", and "continuing 


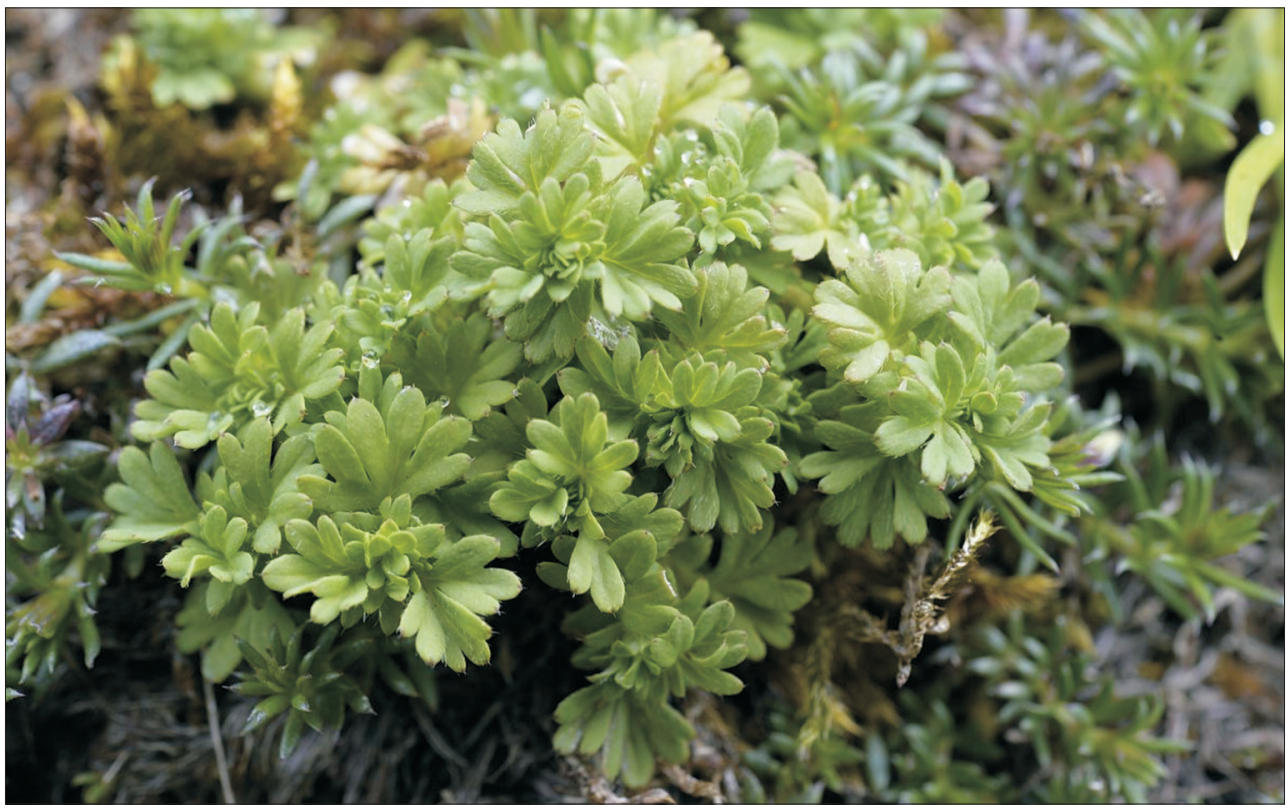

Photo 2. Aphanes australis is an annual plant, in Norway usually behaving as a summer annual. Seeds often enter dormancy if spring temperatures and soil humidity are too low. This has a huge effect on the germination of seeds and is part of a normal cycle between dormancy and germination. The huge variation in adult plants present each year would have a major impact on the evaluation of red-list status but temporal data on the abundance and frequency of this and most other species hardly exist. (Photo by LundBERG, A.)

decline in population". The time period to be considered is the last ten years. Empirical evidence based on annual data developed during the last ten years does not exist for most

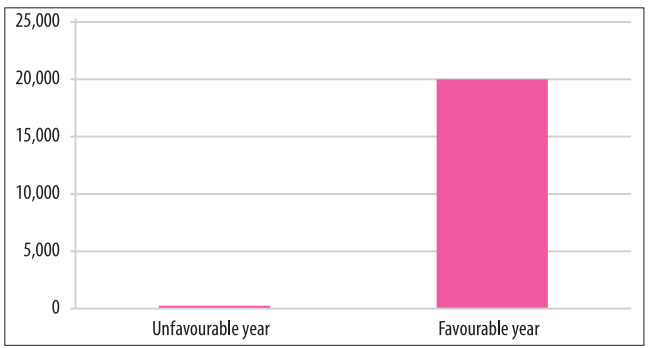

Fig. 7. Variations in spring temperature and soil moisture from year to year causes major changes in total national population size of Aphanes australis in Norway. The huge range between unfavourable and favourable years is a reflection of the natural variation interval of the total population size of that species.
Norwegian species. The knowledge gained from the limited number of national monitoring programs for a few species has developed some vital information but more work has to be done before the criteria for national redlisting set by the government can be met.

\section{Conclusions}

The article discusses methods and approaches to study landscape change at different scales. Historical sources found in state archives were used to analyse the extent of deforestation and later reforestation through secondary succession. Quantitative measures found in the archives were used to identify the part of the land covered by forest through the last 400 years. Landscapes include a number of different types of phenomena, not just forests, and a way to illustrate major land- 
scape attributes present in different periods of time is suggested.

At the biodiversity level, much attention is currently paid to red-listed species. Exact and precise concepts to help identify red-list status for species have been developed by national nature conservation bodies. Population trends of threatened species during a ten-year period should be applied when red-list status is identified. Although the concepts that should be at play in this evaluation are precise and clear, data to be used in the evaluation process hardly exist for most species.

This study suggests how this paradox could be dealt with and solved. Instead of a static model of population size based on information from one or a few years an alternative dynamic model is suggested. A temporal approach can avoid misinterpretations about species' extinction and can instead reveal periods of dormancy among populations. As an alternative to a static perspective on population size the identification of the natural variation interval of a species should be addressed. A temporal approach is vital in such an assessment.

\section{REFERENCES}

BAskin, C.C. and BAskin, J.M. 2014. Seeds. Ecology, biogeography, and evolution of dormancy and germination. San Diego, Academic Press.

Belén, M., Ortega, E., Martino, P. and Otero, I. 2018. Inferring landscape change from differences in landscape character between the current and a reference situation. Ecological Indicators 90.584-593.

BæKKen, I., Vihovde, A.B. and Nordby, H. 2002. Bergen brenner. Om store branner i Bergen. Bergen (Bergen on fire. About large fires in Bergen). Bergen, Det Hanseatiske Museum og Bryggens Museum.

Couch, C., Leontidu, L. and Petschel-Held, G. 2007. Urban sprawl in Europe: landscapes, land-use change E policy. Oxford, Blackwell.

Deák, B., Tóthmérész, B., Valkó, O., SudnikWójcikowska, B., Bragina, T.M., Moysiyenko, I., Apostolova, I., Bүкоv, N., Deмbicz, I. and Töröк, P. 2016. Cultural monuments and nature conservation: The role of kurgans in maintaining steppe vegetation. Biodiversity \& Conservation 25. 2473-2490.

Deák, B., Valkó, O., Török, P., Kelemen, A., Bede, Á., Csathó, A.I. and Tóthmérész, B. 2018. Landscape and habitat and filters jointly drive richness and abundance of grassland specialist plants in terrestrial habitat islands. Landscape Ecology 33. 1117-1132.

Frondoni, R., Mollo, B. and Capotorti, G. 2011. A landscape analysis of land cover change in the Municipality of Rome (Italy): Spatio-temporal characteristics and ecological implications of land cover transitions from 1954 to 2001. Landscape and Urban Planning 100. (1): 117-128.

Heatherington, C., Jorgensen, A. and Walker, S. 2017. Understanding landscape change in a former brownfield site. Landscape Research 10. 1-16.

Helm, A., Hanski, I. and Partel, M. 2006. Slow response of plant species richness to habitat loss and fragmentation. Ecology Letters 9. 72-77.

Henriksen, S. and Hilmo, O. eds. 2015. Norwegian Red List for Species 2015. Trondheim, Artsdatabanken.

Hill, J., Stellmes, A., Udelhoven, Th., Röder, A. and Sommer, S. 2008. Mediterranean desertification and land degradation mapping related land use change syndromes based on satellite observations. Global Planet Change 64. 146-157.

Holt-Jensen, A. 2018. Geography. History and concepts. $5^{\text {th }}$ edition, London, Sage.

Hägerstrand, T. 1995. Nature and society: The challenge of contemporary knowledge. In Expanding environmental perspectives. Lessons of the past, prospects for the future. Eds.: Lundgren, L.J., NiLsson, L.J. and Schlyter, P., Lund, Lund University Press, 165-172.

Hultén, E. and Fries, M. 1986. Atlas of North European vascular plants north of the Tropic of Cancer I-III. Königstein, Koeltz Scientific Books.

JoNEs, M. 1988. Land-tenure and landscape change in fishing communities on the outer coast of Central Norway, c. 1880 to the present. Methodological approaches and modes of explanation. Geografiska Annaler 70B. 197-204.

Kizos, T., Verburg, P.H., Bürgi, M., Gounaridis, D., Plieninger, T., Bieling, C. and Balatsos, T. 2018. From concepts to practice: combining different appraoches to understand drivers of landscape change. Ecology and Society 23. (25): 1-11.

LindgaArd, A. and Henriksen, S. eds. 2018. Norsk rødliste for naturtyper 2018 (Norwegian red-list for nature types 2018). Trondheim, Artsdatabanken.

Lundberg, A. 2002. Lindøy. Historia om folket som budde der og landskapet dei forma (The island of Lindøy. The history of the people who lived there and the landscape they shaped). Nord-Rogaland og Sunnhordland Friluftsråd.

LundberG, A. 2005a. Landscape transformation at Lindøy (Karmøy) 1955-2003 - a response to changes in land ownership and customary law. In Landscape, Law and Justice. Eds.: Jones, M. and Peil, N., Oslo, Novus forlag / The Institute for Comparative Research in Human Culture, 278-287.

LundBerg, A. 2005b. Landskap, vegetasjon og menneske gjennom 400 år (Landscape, vegetation and man through 400 years). Fagbokforlaget, Bergen. 
Lundberg, A. 2008. Changes in the land and the regional identity of western Norway. The case of Sandhåland, Karmøy. In Nordic landscapes. Landscape, Region and Belonging on the Northern Edge of Europe. Eds.: Jones, M. and Olwig, K., Minneapolis, University of Minnesota Press, 344-371.

LundBerg, A. 2010. Conflicts between perception and reality in the management of alien species in forest ecosystems: a Norwegian case study. Landscape Research 35. (3): 319-338.

Lundberg, A. 2015. Faggrunnlag for dvergmarikape, saronnellik, ekornsvingel, islandsgrønkurle, jærflangre, jærtistel og skredmjelt $i$ Noreg. Årsrapport for 2015 (Scientific report on Aphanes australis, Dianthus armeria, Vulpia bromoides, Coeloglossum viride ssp. islandica, Epipactis helleborine var. neerlandica, Serratula tinctoria and Oxytropis campestris ssp. scotica in Norway. Annual report for 2015). Manuscript.

Lundberg, A. 2016. Dvergmarikåpe Aphanes australis i Noreg - utbreiing, økologi og tilstand (Aphanes australis in Norway - distribution, ecology and state). Blyttia 74. 241-251.

LundberG, A. 2017. Jærflangre Epipactis helleborine (L.) Crantz var. neerlandica Verm. i Noreg - utbreiing, økologi og tilstand (Epipactis helleborine [L.] Crantz var. neerlandica Verm. in Norway - distribution, ecology and state). Blyttia 75. 221-232.

Lundberg, A. and Frøland, T. 2018. Faggrunnlag for purpurmarihand Dactylorhiza purpurella. Arsrapport 2018. (National monitoring of Dactylorhiza purpurella in Norway. Annual report for 2018). Miljødirektoratet, Trondheim .

Novák, T.J., Incze, J., Spohn, M., Glina, B. and Giani, L. 2014. Soil and vegetation transformation in abandoned vineyards of the Tokaj Nagy-Hill, Hungary. Catena 123. 88-98.
Pitkënen, P.T., Kumpulainen, J., Lehtinen, J., SiHvonen, M. and KäYнкÖA, N. 2016. Landscape history improves detection of marginal habitats on seminatural grasslands. Science of the Total Environment 539. 359-369.

Plieninger, T. 2006. Habitat loss, fragmentation, and alteration - Quantifying the impact of land-use changes on a Spanish dehesa landscape by use of aerial photography and GIS. Landscape Ecology 21. 91-105.

SkJeggedal, T. 2005. The planning and building act outside urban areas - unbound ambitions, lilited possibilities. In Landscape, Law and Justice. Eds.: Jones, M. and PeIL, N., Oslo, Novus forlag / The Institute for Comparative Research in Human Culture, 152-163.

Szabó, S., Bertalan, L., Kerekes, Á. and Novák, T.J. 2015. Possibilities of land use change analysis in a mountainous rural area: a methodological approach. International Journal of Geographical Information Science 30. 708-726.

TöröK, P., DeÁK, B., Vida, E., VAlkó. O., LengYel, S. and Tóthmerész, B. 2010. Restoring grassland biodiversity: Sowing low-diversity seed mixturescan lead to rapid favourable changes. Biological Conservation 143. 806-812.

Töröк, P., Helm, A., Kiehl, K., Buisson, E. and Valkó, O. 2018. Beyond the species pool: modification of species dispersal, establishment, and assembly by habitat restoration. Restoration Ecology 26. 65-72.

YANG, Y., Zhang, S., LiU, Y., XING, X. and Sherbinin, A. 2017. Analysing historical land use changes using a Historical Land Use Reconstruction Model: a case study in Zhenlai Country, northeastern China. Scientific Reports 7. 41275. Doi: 10.1038/srep41275 